\title{
Gastric ATPase phosphorylation/dephosphorylation monitored by new FTIR-based BIA-ATR biosensors
}

\author{
A. Goldsztein ${ }^{\text {a,* }}$, S. Babar ${ }^{\text {a }}$, M. Voué ${ }^{\text {b,c }}$, J. De Coninck ${ }^{\text {b }}$, J. Conti ${ }^{\text {b }}$, J. Marchand-Brynaert ${ }^{\text {d }}$, \\ S. Devouge ${ }^{\mathrm{d}}$, F. Homblé ${ }^{\mathrm{a}}$ and E. Goormaghtigh ${ }^{\mathrm{a}}$

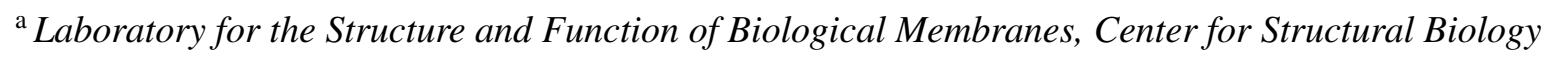 \\ and Bioinformatics, Université Libre de Bruxelles, Belgium \\ ${ }^{\mathrm{b}}$ Laboratoire de Physique des Surfaces et des Interfaces, Université de Mons, Mons, Belgium \\ ${ }^{\mathrm{c}}$ Physique des Matériaux et Optique, Université de Mons, Mons, Belgium \\ ${ }^{\mathrm{d}}$ Unité de Chimie Organique et Médicinale, Université Catholique de Louvain, Bâtiment Lavoisier, \\ Louvain-la-Neuve, Belgium
}

\begin{abstract}
Biosensors are composite devices suitable for the investigation of receptor-ligand interactions. In this paper we present the specific application to a membrane embedded protein of a new sensor device, so-called BIA-ATR, based on Attenuated Total Reflection-Fourier Transform Infrared (ATR-FTIR) spectroscopy. It consists in a functionalised ATR germanium crystal whose surface has been covalently modified to adsorb a biomembrane. Detection of the ligand-receptor interaction is achieved using FTIR spectroscopy. We report the specific detection of the phosphorylation/dephosphorylation of the $\mathrm{H}^{+} / \mathrm{K}^{+}$ gastric ATPase. The $\mathrm{H}^{+}, \mathrm{K}^{+}$-ATPase is a particularly large protein entity. This glycosylated protein contains more than 1300 residues and is embedded in a lipid membrane. Yet we demonstrate that the BIA-ATR sensor is capable of monitoring the binding of a single phosphate on such a large protein entity. Furthermore, we also demonstrate the potential of the approach to monitor the kinetics of binding and dissociation of the ligand.
\end{abstract}

Keywords: Gastric ATPase, BIA-ATR biosensors, FTIR, phosphorylation

\section{Introduction}

Attenuated total reflection Fourier transform infrared spectroscopy (ATR-FTIR) is one of the most powerful methods for recording infrared spectra of biological materials in general, and of biological membranes in particular. It is fast, yields a strong signal with only a few micrograms of sample, and importantly, allows information about the structure and orientation of various parts of the molecules under study to be evaluated [4]. While mid-infrared radiation has been mostly used for fundamental research on molecular structure, it is becoming an interesting alternative in sensor research. In addition

\footnotetext{
* Corresponding author: Andréa Goldsztein, Center for Structural Biology and Bioinformatics, Laboratory for the Structure and Function of Biological Membranes, Campus Plaine CP206/02, Université Libre de Bruxelles, Bld du Triomphe 2, CP206/2, B1050 Brussels, Belgium. Tel.: +32 265053 62; Fax: +32 265053 82; E-mail: angoldsz@ulb.ac.be.
} 
to monitoring ligand binding, it provides a full spectrum characterizing both molecule nature and 3D structure. Protein conformation in particular is easily investigated $[4,5]$ and may be of major interest for the understanding of the action of drugs on their protein receptors. Another interesting feature of the IR detection is that it allows the concentrations to be determined from the molar integrated extinction coefficients. We recently demonstrated that chemical modification of germanium ATR crystals is possible and provides stable surfaces suitable for sensor applications $[2,3,10]$.

The gastric $\mathrm{H}^{+}, \mathrm{K}^{+}$-ATPase is the protein responsible for acid secretion in the stomach. It is an electroneutral pump that transports protons from the cytoplasm of stomach parietal cell and creates a large $\mathrm{pH}$ gradient in exchange for internalization of potassium $[9,11]$. The energy for these transports comes from ATP hydrolysis. The $\mathrm{H}^{+}, \mathrm{K}^{+}$-ATPase also belongs to the ubiquitous P-type ATPase family [1] which is characterized by the formation of a covalent aspartylphosphate bond during the catalytic cycle.

In this paper we attempted the challenging monitoring of the $\mathrm{H}^{+}, \mathrm{K}^{+}$-ATPase phosphorylation/dephosphorylation. The $\mathrm{H}^{+}, \mathrm{K}^{+}$-ATPase is a particularly large protein entity. This glycosylated protein contains more than 1300 residues and is embedded in a lipid membrane. Yet, we demonstrate that sensors based on the BIA-ATR technology are capable of monitoring the binding of a single phosphate on such a large protein entity.

\section{Methods}

Attenuated total reflection infrared (ATR-FTIR) spectra were obtained on a Bruker IFS 55 FTIR spectrophotometer (Ettlingen, Germany) equipped with a MCT detector at a resolution of $2 \mathrm{~cm}^{-1} .128$ scans were accumulated for each spectrum. The spectrometer was continuously purged with dry air (Whatman 75-62, Haverhill, MA, USA). Trapezoidal-shaped germanium crystals $\left(2 \times 20 \times 50 \mathrm{~mm}^{3}\right)$ were purchased from ACM (Villiers St. Frédéric, France) and placed on a vertical ATR device from Specac, resulting in 25 internal reflections. Surface modification was obtained as described earlier $[2,3,10]$ by silanisation with a self-assembled monolayer of octadecyltrichlorosilane in order to build a hydrophobic surface suitable for strongly adsorbing biological membranes. Briefly, the ATR element was immersed in $\mathrm{HNO}_{3}(38 \%)$ during 1 min and rinsed in MilliQ water. Afterwards, the surface was activated in a mixture of $\mathrm{H}_{2} \mathrm{O}_{2}$ and ethanedioic acid (10\%) during $5 \mathrm{~min}$. Finally, the surface was abundantly rinsed under a MilliQ water flow [10]. The activated ATR elements were immersed in a solution of OTS $(0.08 \% \mathrm{v}: \mathrm{v})$ in hexadecane: $\mathrm{CCl}_{4}$ (ratio 7:3) during $16 \mathrm{~h}$ at $12^{\circ} \mathrm{C}$.

Tubulovesicle membranes containing the $\mathrm{H}^{+}, \mathrm{K}^{+}$-ATPase were prepared from pig stomach as previously described [8]. The buffer used was $50 \mathrm{mM}$ Hepes, $20 \mathrm{mM} \mathrm{KCl}$ and $2 \mathrm{mM} \mathrm{NaCl}$. $2 \mathrm{mM} \mathrm{Mg}$-ATP was added when indicated. The flow rate in the cell was $0.5 \mathrm{ml} / \mathrm{min}$.

The software used for data processing was written under MatLab (Mathworks Inc, Natick, MA, USA).

\section{Results and discussion}

$2 \mu \mathrm{l}$ of tubulovesicles membranes containing ca $150 \mu \mathrm{g}$ of ATPase were deposited on the functionalised germanium crystal and dried under a flow of nitrogen to obtain an oriented multilayer stack of membranes as demonstrated elsewhere [6]. The crystal was then flushed with the buffer (see Section 2). After 10 min a background was recorded. Figure 1 represents the spectra obtained every minute when the cell was flushed by 4 sequences of buffer $+2 \mathrm{mM}$ of ATP followed by the buffer alone. The major changes were observed in the $1300-1000 \mathrm{~cm}^{-1}$, a region assigned to phosphate vibrations. The major 

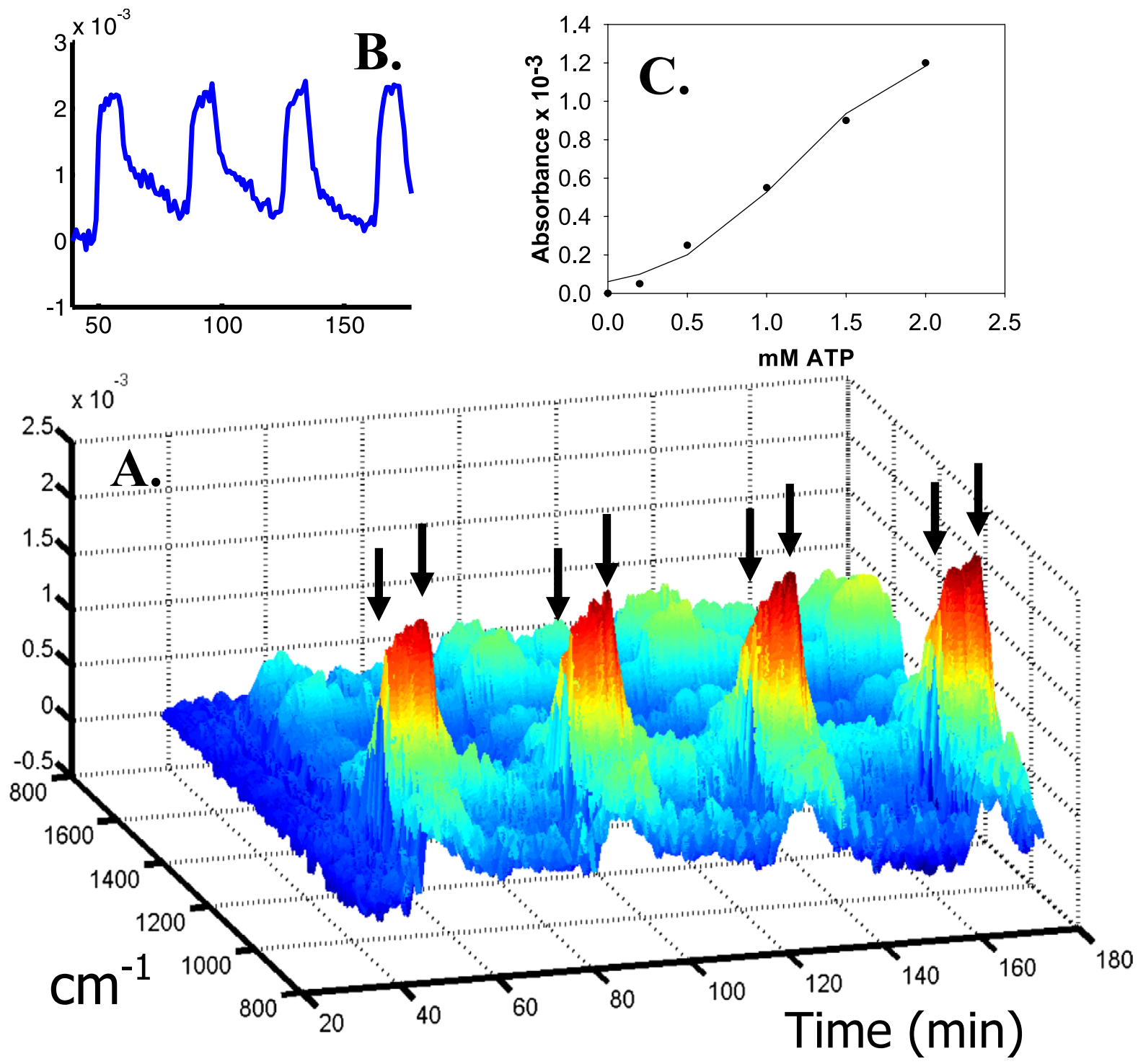

Fig. 1. (A) Series of infrared spectra recorded between 1900 and $900 \mathrm{~cm}^{-1}$ of a tubulovesicle multilayer stack exposed to 4 rounds of ATP addition followed by a wash. The addition and removal of Mg-ATP in the buffer are indicated by the arrows. (B) Reports the time evolution of the absorbance at $1077 \mathrm{~cm}^{-1}$ when $2 \mathrm{mM} \mathrm{Mg-ATP}$ is added and removed from the buffer flushing the cell. (C) Reports the evolution of the absorbance at $1077 \mathrm{~cm}^{-1}$ when the Mg-ATP concentration is increased from 0 to $2.5 \mathrm{mM}$.

band was found at $1077 \mathrm{~cm}^{-1}$ and is assigned to the aspartyl phosphate intermediate. This assignment results from the comparison between the spectra obtained in the presence of Mg-ATP (Fig. 1), the spectrum of Mg-ATP in solution and the spectrum of acetyl phosphate [7]. The spectra reported in Fig. 1 are very similar to the spectra of acetyl phosphate spectra but clearly distinct from those of Mg-ATP (not shown). As acetyl phosphate is an analogue of the physiologically formed aspartyl-phosphate covalent complex, it is legitimate to assign the spectra changes observed to the phosphorylation of the ATPase on one aspartate residue. Upon removal of the Mg-ATP from the buffer, in the presence of $\mathrm{KCl}$ 
in the buffer, the aspartyl-phosphate is hydrolyzed and the phosphate is released in the medium. The kinetic of the dephosphorylation is better observed on the inset (Fig. 1(B)) where the absorbance at $1077 \mathrm{~cm}^{-1}$ is reported in the course of the experiment. Because of the reversibility of the phosphorylation, the experiment could be reproduced with different $\mathrm{Mg}$-ATP concentrations and the evolution of the phosphorylation level could be monitored accordingly as reported in Fig. 1(C).

The approach followed here to build a biosensor allowed the detection of a single aspartyl-phosphate group on the gastric ATPase which is a large multimeric protein complex with a molecular weight above $1300 \mathrm{kDa}$. In addition the protein is glycosylated and embedded in a lipid membrane, which further increases the size of the functional entity. So we demonstrate that the small size of the receptor relative to the size of the ligand (the ratio is about 5000:1 w:w) is not an obstacle for the detection of ligand binding. Furthermore, we also demonstrate the potential to monitor the kinetics of binding and dissociation. This opens a new door for future investigations on a wide range of molecular interactions.

\section{Acknowledgement}

This research has been supported by grants WDU and WALEO2 from the Région Wallonne (Belgium).

\section{References}

[1] K.B. Axelsen and M.G. Palmgren, Evolution of substrate specificities in the P-type ATPase superfamily, J. Mol. Evol. 46 (1998), 84-101.

[2] S. Devouge, J. Conti, A. Goldsztein, E. Gosselin, A. Brans, M. Voué, J. De Coninck, F. Homblé, E. Goormaghtigh and J. Marchand-Brynaert, Surface functionalization of germanium ATR devices for use in FTIR-biosensors, J. Coll. Interf. Sci. 332 (2009), 408-415.

[3] A. Goldzstein, A. Aamouche, F. Homblé, M. Voué, J. Conti, J. De Coninck, S. Devouge, J. Marchand-Brynaert and E. Goormaghtigh, Ligand-receptor interactions in complex media: A new type of biosensors for the detection of coagulation factor VIII, Biosens. Bioelectron. 24 (2009), 1831-1836.

[4] E. Goormaghtigh, V. Raussens and J.M. Ruysschaert, Attenuated total reflection infrared spectroscopy of proteins and lipids in biological membranes, Biochim. Biophys. Acta 1422 (1999), 105-185.

[5] E. Goormaghtigh, J.M. Ruysschaert and V. Raussens, Evaluation of the information content in infrared spectra for protein secondary structure determination, Biophys. J. 90 (2006), 2946-2957.

[6] D. Ivanov, N. Dubreuil, V. Raussens, J.M. Ruysschaert and E. Goormaghtigh, Evaluation of the ordering of membranes in multilayer stacks built on an ATR-FTIR germanium crystal with atomic force microscopy: The case of the $\mathrm{H}^{+}, \mathrm{K}^{+}$ATPase-containing gastric tubulovesicle membranes, Biophys. J. 87 (2004), 1307-1315.

[7] M. Liu, M. Krasteva and A. Barth, Interactions of phosphate groups of ATP and aspartyl phosphate with the sarcoplasmic reticulum $\mathrm{Ca}^{2+}$-ATPase: An FTIR study, Biophys. J. 89 (2005), 4352-4363.

[8] V. Raussens, J.M. Ruysschaert and E. Goormaghtigh, Fourier transform infrared spectroscopy study of the secondary structure of the gastric $\mathrm{H}^{+}, \mathrm{K}^{+}$-ATPase and of its membrane-associated proteolytic peptides, J. Biol. Chem. 272 (1997), 262-270.

[9] G. Sachs, H.H. Chang, E. Rabon, R. Schackman, M. Lewin and G. Saccomani, A nonelectrogenic $\mathrm{H}^{+}$pump in plasma membranes of hog stomach, J. Biol. Chem. 251 (1976), 7690-7698.

[10] M. Voué, E. Goormaghtigh, F. Homblé, J. Marchand-Brynaert, J. Conti, S. Devouge and J. De Coninck, Biochemical interaction analysis on ATR devices: A wet chemistry approach for surface functionalization, Langmuir 23 (2007), 949955.

[11] X.B. Yao and J.G. Forte, Cell biology of acid secretion by the parietal cell, Ann. Rev. Physiol. 65 (2003), $103-131$. 


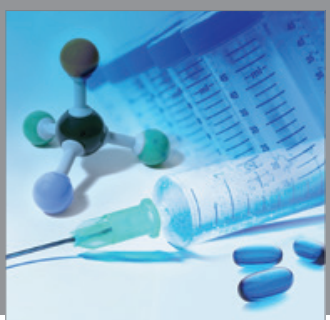

International Journal of

Medicinal Chemistry

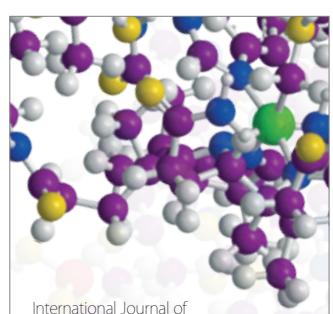

Carbohydrate Chemistry

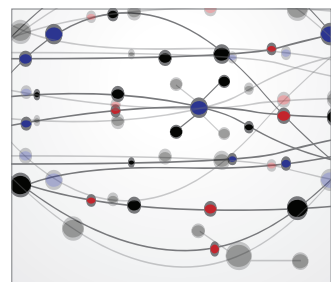

The Scientific World Journal
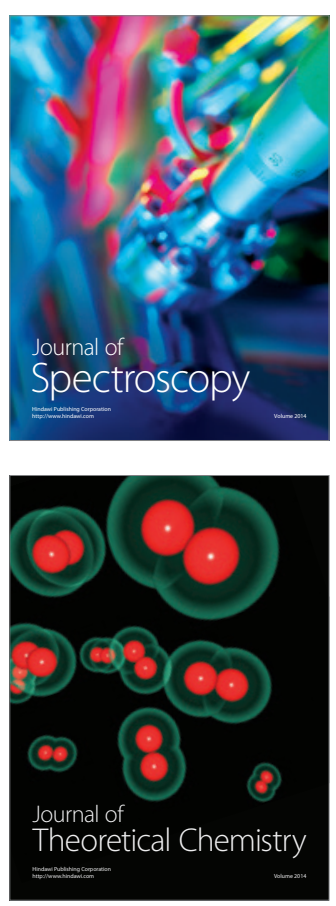
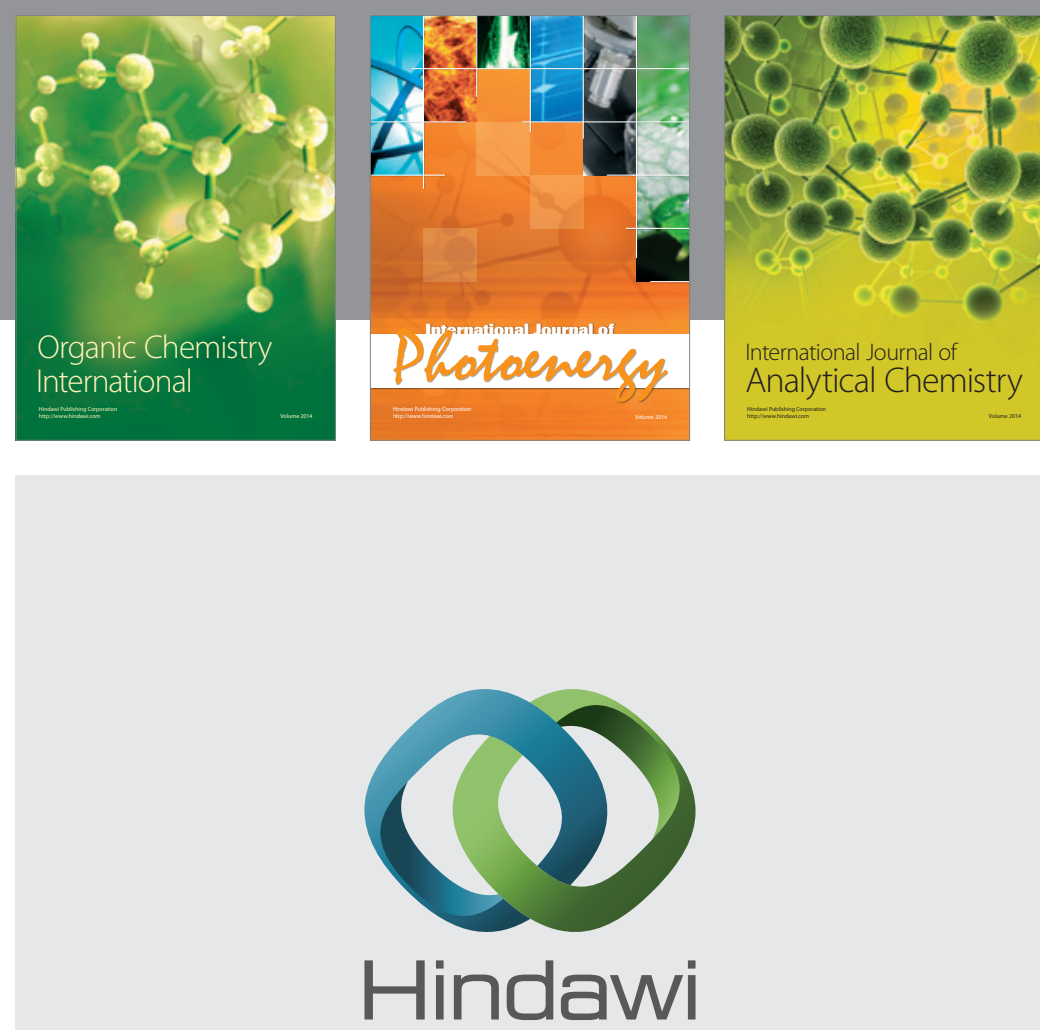

Submit your manuscripts at

http://www.hindawi.com
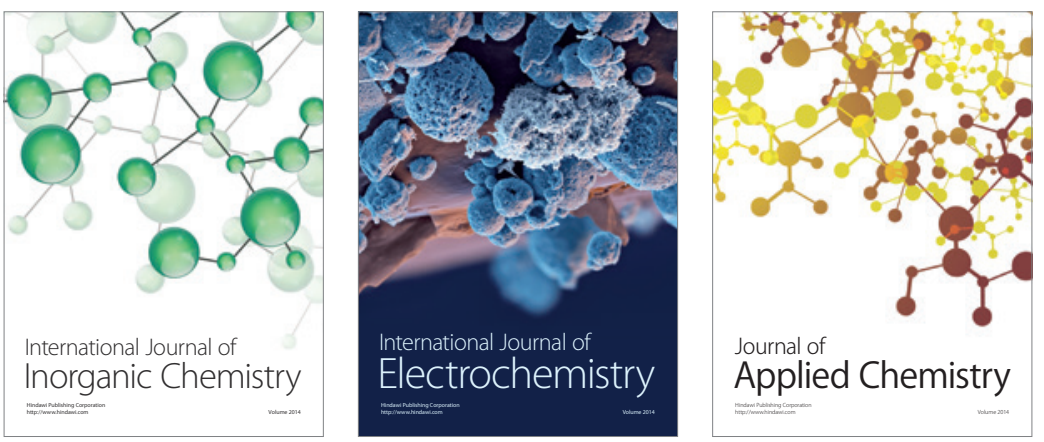

Journal of

Applied Chemistry
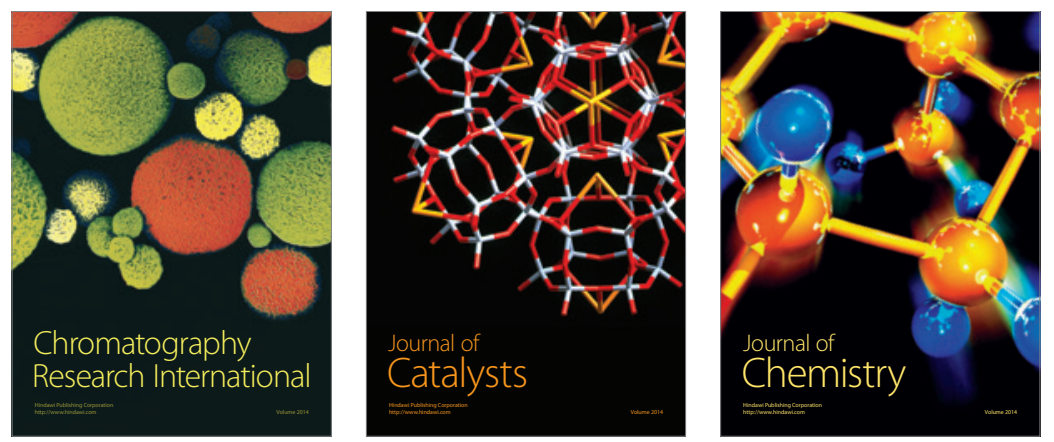
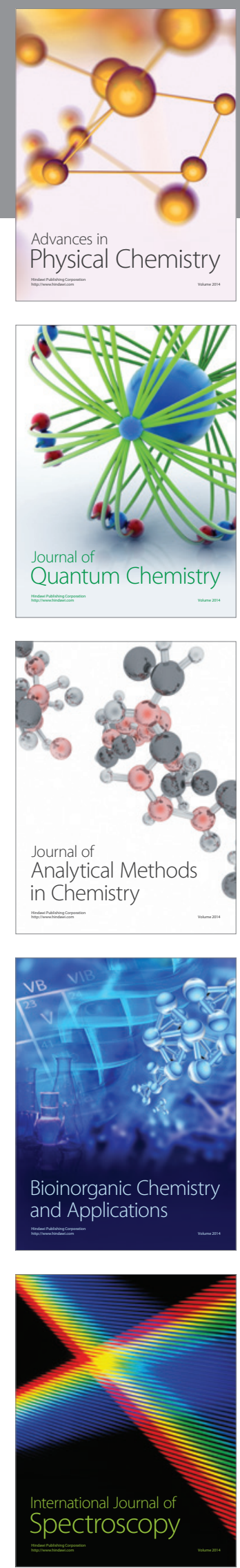